\title{
CUSTOMER ORIENTATION AND INNOVATIVENESS: DiFFERING ROLES IN NEW AND OLD EUROPE
}

\author{
by
}

Vasilis Theoharakis ${ }^{1}$ and Graham Hooley ${ }^{2}$
${ }^{1}$ Associate Professor of Marketing \& Entrepreneurship and Associate Dean, ALBA Graduate Business School, Athinas \& Areos 2A, Vouliagmeni 166 71, Athens, Greece
Tel: + 30210896 4531, Fax: +30 210896 4737, e-mail: vtheohar@alba.edu.gr $\&$

Senior Lecturer in Marketing, Aston Business School, Aston University, Birmingham, B4 7ET, United Kingdom

\footnotetext{
${ }^{2}$ Professor of Marketing and Senior Pro-Vice-Chancellor, Aston University, Birmingham, B4 7ET, United Kingdom

Tel: + 44 (0) 121359 3011, Fax: +44 (0) 121333 4313, e-mail: g.j.hooley@aston.ac.uk
} 


\title{
Customer ORIENTATION AND INNOVATIVEnESS: DifFERING ROLES IN NEW AND OLD EUROPE
}

\begin{abstract}
Burgess and Steenkamp (2006) have pointed out that marketing knowledge derives almost exclusively from research conducted in high income, industrialized countries. However, the generalizability of marketing knowledge should also be tested in emerging markets. We demonstrate that returns on customer orientation and organizational innovativeness play out differently in New versus Old Europe. Contrary to previous research, we find that customer focus is at least as important in New Europe as in our Old European country, while organizational innovativeness appears more important in New Europe to drive both customer service and financial performance.
\end{abstract}

Keywords: Emerging Markets, Customer Orientation, Organizational Innovativeness, Differentiation, Sustainable Competitive Advantage 


\section{CUSTOMER Orientation AND INNOVATIVENESS: DifFERING Roles IN NEW AND OLD EUROPE}

\section{Introduction}

Burgess and Steenkamp (2006) point out that, while the marketing discipline has made substantial progress in addressing scientific and managerial problems over the past few decades, the knowledge derived is almost exclusively based on research conducted in high income industrialized economies. There has been relatively little research conducted in emerging markets where the economic, social and cultural context of business may be very different. They therefore question the generalizability of findings outside the context of highly industrialized economies. Two cornerstones of marketing theory, the impacts of market orientation and innovation on performance, are prime examples where the bulk of the research conducted to date has been performed in highly industrialized countries. This paper seeks to contribute to the field by testing these relationships simultaneously in the context of a highly industrialized country in Old Europe and two emerging markets in New Europe.

For several decades, customer focus has been described as the cornerstone of marketing (Levitt, 1960) and as the major component of market orientation (Deshpandé \& Farley, 1998). The predictive power of market orientation on business performance has been the subject of considerable empirical research. Although this relationship has been challenged (Langerak, 2003), meta-analyses have found the effect of market orientation on business performance to be positive and significant, but relatively weak as market orientation only explains about $12 \%$ of the variance in business performance (Cano, Carrillat, \& Jaramillo, 2004). Furthermore, recent meta-analyses have also shown market orientation to have a stronger effect in western economies vs. Eastern European economies (Ellis, 2006; Kirca, Jayachandran, \& Bearden, 2005). The surprise lies in the fact that Eastern European countries that form the New Europe, have traditionally experienced lower levels of service, which suggests that customers should appreciate the increased attention they receive from more customer-oriented companies. This customer appreciation should translate to superior firm performance, yet this is not reflected in these meta-analyses. Moreover, the majority of market orientation studies have focused on short term financial performance measures, and have paid little attention to the firm's ability to sustain a competitive advantage in the longer term (Kirca, Jayachandran, \& Bearden, 2005). Moreover, there has been relatively little research on sustainable competitive 
advantage-enhancing practices in emerging Eastern European economies (Hooley et al., 2000).

Conceptually, it seems reasonable to believe that firms in emerging economies have more to benefit from organizational innovativeness as they have a need to "catch up" in terms of processes that will enable them to compete more effectively in the global market-based economy. This suggests that innovation in working methods and processes plays a significant role, as it did for Japan after WW2, which was an emerging economy at the time. In a similar vein, Gaal (2004) reports on process innovation in agricultural marketing in Hungary, which has substantially improved performance in international marketing. For example, firms were able to market 'Hungarian' wine more effectively by promoting differentiation of a wine's country of origin, leading to a doubling of Hungarian wine exports to the UK (1993 to 2004). This differentiation enabled them to avoid having to compete on price. Gorenje, the leading Slovenian manufacturer and marketer of home appliances, has set its goal to be the most innovative and design-minded appliance maker in the world within 5 years (Slovene Press Agency, 2005). This is being achieved in part through innovations in online marketing, and boosting its image in foreign markets. One would therefore expect that the ability of Eastern European firms to reap the benefits of customer orientation would depend more heavily on their innovativeness. Thus, firms from these countries can compete by overcoming established practices that do not focus on the customer. Therefore, it is important to examine the interplay between customer orientation and organizational innovativeness across New and Old Europe.

Firms have been described as facing a dilemma between serving customers for short term financial profits or for enhancing long term position by creating customers through the development of unique and differentiated products (Berthon, Hulbert, \& Pitt, 1999). While the former is an act of customer focus the latter is a result of organizational innovativeness. Given that serving the customer would involve the delivery of superior levels of customer service performance, the aforementioned logic also implies that customer service performance and product differentiation, which we refer to as the service-product offering, mediate the relationship between customer focus and organizational innovativeness with respect to performance. Since customer orientation and organizational innovativeness may have a different effect on organizational performance, it is important to examine the effect both on short term financial performance and on longer term sustainable competitive advantage. 
This paper seeks to contribute to this discussion in a number of ways. First, based on the call of Burgess and Steenkamp (2006) to advance marketing science via research in emerging markets, we examine the integration of customer orientation and organizational innovativeness in three different contexts: Hungary, Slovenia and the UK. The emerging New European markets present us with a natural laboratory for testing theories developed in industrialized countries and discovering the underlying mechanisms in these markets (Burgess \& Steenkamp, 2006). Specifically, we hypothesize organizational innovativeness will increasingly act as an enabler for customer orientation practices in the emerging New European markets. Second, it contributes by further examining the emerging literature that has raised the need to integrate market orientation measures and innovativeness (Liu, Luo, \& Shi, 2002; Menguc \& Auh, 2006). The basic premise for this integration is that while customer orientation leads a company to allocate resources to current customers, organizational innovativeness leads to a proactive reconfiguration of resources in order to address future customers and their needs. Third, we examine the mediating role of the serviceproduct offering with organizational performance to further explore how firms both serve and create customers. Fourth, we consider firm performance over different time frames. We hypothesize that better served customers lead to short term financial performance, while the creation of differentiated products is more directly linked with long term sustainable competitive advantage. The former performance measure is most commonly used in marketing studies, while the latter is most commonly used in the strategic management literature, offering a possible explanation for the different emphases on market orientation and innovation in these literatures.

We demonstrate that differences in the effect of customer orientation and organizational innovativeness on service performance are moderated by the national context. Customer orientation also proved to be a source of long term, sustainable competitive advantage for our New European countries, but this was not the case for our Old European economy. We also find organizational innovativeness to have a stronger effect on customer service and financial performance in our New European economies. However, we find customer orientation's total contribution to short term financial performance in our New European economies to be at similar levels with our Old European economy. This is contrary to previous findings that present customer orientation as having a smaller effect in Eastern European or emerging markets in general (Ellis, 2006; Kirca, Jayachandran, \& Bearden, 2005). 
The paper is organized as follows. First we present our theoretical background, conceptual framework and methodology. We then introduce an empirical study designed and conducted in order to test our conceptual model. Results are then presented and implications are discussed.

\section{Theoretical background}

Based on earlier defined market orientation constructs, numerous studies in the United States (Deshpandé, Farley, \& Webster, 1993; Jaworski \& Kohli, 1993; Slater \& Narver, 2000), Europe (Cadogan \& Diamantopoulos, 1995; Greenley, 1995; Hooley et al., 2000) and other parts of the world (Gray, Matear, Boshoff, \& Matheson, 1999) have taken place. As stated earlier, while market orientation scales have been generally linked to firm performance, a number of studies have found mixed results between market orientation and firm performance measures (Diamantopoulos \& Hart, 1993; Jaworski \& Kohli, 1993; Langerak, 2003). For example, some studies did not find the direct relationship between customer orientation and performance to be statistically significant (Han, Kim, \& Srivastava, 1998; Noble, Sinha, \& Kumar, 2002), and some have even found market orientation to have a negative influence on firm performance after a crisis (Grewal \& Tansuhaj, 2001). More recently, Narver, Slater and MacLachlan (2004) developed a proactive market orientation scale addressing concerns that the original operationalization of market orientation appears to be primarily reactive in nature.

When Deshpandé and Farley (1998) examined three popular market orientation scales together, they found these scales to be similar to one another in terms of the various validity measures and their correlation with performance. The same authors, in a synthesis of the three scales, identified customer focus as the single factor that dominated market orientation; a finding consistent with the argument that market orientation scales stress serving the customer (Berthon, Hulbert, \& Pitt, 1999). Given the dominant role of the customer orientation subscale within market orientation, we focus our analysis on this component, which has paradoxically been the element most criticized by Christensen and Bower (1996). More specifically, customer orientation has been described as the set of behaviors and beliefs that places a priority on customers' interests (Rindfleisch \& Moorman, 2003).

Christensen and Bower (1996) argued that listening too carefully to customers results only in marginal incremental product changes, rather than more substantial improvements that might attract new customers. They conclude that leading firms often fail to replicate their initial market success not due to technological incompetence, but due to the self-imposed strait- 
jackets created through slavishly following existing customers. The basic premise for this argument is that resource allocation decisions that influence a firm's ability to innovate are often made based on current, rather than future, customer needs. However, Slater and Narver (1998) make the distinction between firms being market oriented and 'customer-led'; the basic premise of their argument is that market-oriented businesses are committed to understanding both expressed and latent customer needs. While highly successful firms are expected to be able to be both market driven and to drive markets (Jaworski, Kohli, \& Sahay, 2000), contemporary management theories have not been found to be applicable in all international research contexts due to differences in national culture (Steensma, Marino, Weaver, \& Dickson, 2000). Since the effect of market orientation on firm performance has been found to be moderated by national context (Kirca, Jayachandran, \& Bearden, 2005) and firms in transition economies may have an even higher dependency on innovativeness than developed economies, thus, studies that relate to market driven and market driving practices need to do so in a multicultural setting.

In a manner similar to that adopted by proponents of customer orientation, Danneels (2003) argues that tight coupling with customers "leads to a better understanding of customers' needs, closer tailoring of products and services, higher customer satisfaction, easier forecasting of demand, and closer relationships." However, loose coupling with customers allows firms to remain flexible to seek wider opportunities and detect broader threats. The logic behind loose coupling with customers and market driving relates to the Schumpeterian paradigm where competition is innovation-based, leading to the 'creative destruction' of existing competencies (Schumpeter, 1934). In New Europe, the improvement of existing competencies is ever more critical; firms from these countries have to develop new competencies that would enable them to become competitive in the new market-based economy. During the 1990s, a major objective of governments in transition economies was to encourage entrepreneurship and innovation (Cox et al., 1999). This was often pursued through privatization of state owned enterprises (SOEs) and the encouragement of foreign direct investment. However, Eastern European countries have still been found to have different economic cultures and remain at different levels of development (Zver, Zivco, \& Bobek, 2004).

At the same time firms have to both serve customers and create new ones; customer creation is achieved by developing unique new products. However, the new product development 
literature typically deals with product advantage, which is defined by a product's uniqueness and innovativeness (Henard \& Szymanski, 2001; Langerak, Hultink, \& Robben, 2004) without simultaneously considering service performance. This comes as a surprise given that the phrase "every business is a service business", which is rooted in the service and relationship management literature (Grönroos, 1999), has become a cliché among marketers. Therefore, a need exists to examine the effect of reactive market-driven behaviors and the innovative market-driving behaviors on the firm's ability to serve and create customers. Further, the effect of these two behaviors and their resulting products and service levels need to be examined not only with respect to their ability to generate short term profits, as is typically the case in marketing, but also with their ability to achieve long term sustainable competitive advantage. The examination of both short- and long-term performance measures will contribute to reconciling the debate between strategic management and marketing (Christensen \& Bower, 1996).

\section{Conceptual framework}

Although the link between customer orientation and performance has been challenged (Noble, Sinha, \& Kumar, 2002), the predominantly western-based services literature has demonstrated that customer orientation leads to improved customer service performance (Brady \& Cronin, 2001). Moreover, it is the customer focus achieved by customer-oriented firms that leads to better served customers (Berthon, Hulbert, \& Pitt, 1999). Following the satisfaction profit chain paradigm (Kamakura, Mittal, de Rosa, \& Mazzon, 2002), customer service performance has been linked with higher financial performance - high levels of customer service lead to higher customer retention rates resulting in greater sales volume and larger market share (Rust \& Zahorik, 1993). Benefits that delight the customer, but are most easily duplicated, will not provide a sustainable source of competitive advantage (Berry, 1995). This is consistent with the basic premise of the argument that serving the customer is a source of short term financial gains rather than long term competitiveness (Berthon, Hulbert, \& Pitt, 1999; Christensen \& Bower, 1996). In other words, service performance can only delight and create loyal customers if it is scarce in the marketplace. For example, benefits such as price reduction can easily be copied, though some claim that this is not always the case for benefits such as faster or more responsive service (Hennig-Thurau, 2002).

Organizational innovativeness or product innovation have been found to mediate the relationship between market orientation and organizational performance (Han, Kim, \& 
Srivastava, 1998; Hurley \& Hult, 1998; Kirca, Jayachandran, \& Bearden, 2005; Leskiewicz Sandvik \& Sandvik, 2003). Therefore, organizations that have innovative internal processes will continuously develop new ways to serve the customer more efficiently and more effectively and create new customers by offering differentiated products. This is also echoed by Slater and Narver (1995) who state that "market orientation may not encourage a sufficient willingness to take risks" and Hamel and Prahalad (1991) who referred to market oriented businesses as suffering from the "tyranny of the served market". Specifically, customer orientation was not linked with product novelty, product similarity, or product advantage (Gatignon \& Xuereb, 1997).

Insert Figure 1 about here

Our conceptual framework (Figure 1) summarizes our discussion and will serve as the basis for testing our model. While we expect customer orientation to be linked with innovativeness, we do not expect it to be directly linked with differentiated products; organizational innovativeness should fully mediate the "customer orientation - product differentiation" relationship ${ }^{1}$. Product differentiation is a central element of the marketing mix that is broadly sought by marketers as it makes the product distinct, offers a unique selling proposition, and leads to higher financial performance (Buzzell \& Gale, 1987; Dickson \& Ginter, 1987; Gatignon \& Xuereb, 1997). Furthermore, it is more difficult for competitors to imitate differentiated products, leading to a more sustainable the competitive advantage (Kuester, Homburg, \& Robertson, 1999).

\subsection{A Comparison of New versus Old Europe}

Deshpandé and Farley (2004) state that only a minority of companies in transition countries that are moving towards more market-driven economies apply market-oriented practices. Moreover, the market orientation-performance link has been found to be stronger in mature industrialized countries than it is in emerging economies (Ellis, 2006). This link has been described as weaker in countries where uncertainty avoidance was higher (Kirca, Jayachandran, \& Bearden, 2005). This is supported by the fact that the emerging New European countries tend to have high uncertainty avoidance cultures (Hofstede, 2001). We therefore expect national context to have a clear effect on the strength of the relationships described by our conceptual framework. This is consistent with research in other areas that has demonstrated that new product growth patterns (Stremersch \& Tellis, 2004) and even

\footnotetext{
${ }^{1}$ We thank an anonymous reviewer for this comment.
} 
Consumer Confidence Indicators (Lemmens, Croux, \& Dekimpe, 2007) differ substantially across different European regions.

Before the fall of communism, consumers from the emerging economies of New Europe often queued to buy poor quality goods, in scant supply, produced by a centrally planned economy. As Money and Colton (2000) note, for these countries "customer service did not exist, because, in theory and practice, customers did not exist". However, even under the new market-economy conditions, the attitudes and skills of sales personnel still lag behind (Vadi \& Suuroja, 2006). Given the customer service gap compared to their western counterparts, we expect firms from less developed transition economies that manage to deliver higher levels of customer service performance than their competitors to enjoy a higher financial benefit and competitive advantage. In addition, we expect the effect of organizational innovativeness on customer service performance to be moderated by the national context i.e. the effect should be stronger in New European economies that face a higher degree of bureaucracy than in Old Europe (Deshpandé \& Farley, 2004). Furthermore, not only is uncertainty avoidance considerably higher in these transition countries, but as previously described, customer service practices were originally at a considerably lower level than their western counterparts. This suggests that the change organizational innovativeness can bring will have a bigger effect on improving customer service performance in New Europe vs. Old Europe.

\section{Methodology}

\subsection{Sample and data collection}

Data were collected in Hungary, Slovenia and the UK from a cross-sectional sample drawn from established company directories for each country. As Burgess and Steenkamp (2006) recommended, our study has been driven by the need to test theories developed in western industrialized economies in the emerging economies of New Europe. The criteria for selecting these countries were both pragmatic - the need for reliable research collaborators in each country investigated, and conceptual - variation in cultural and economic context across countries (Holzmüller \& Stöllnberger, 1994).

Hungary is an emerging market that benefited significantly from foreign direct investment from the USA, Germany, UK, and France (among others) during the 1990s. Slovenia is a model of economic success and stability for its neighbors in the former Yugoslavia and enjoys a GDP per capita substantially higher than any of the other transition economies of Central 
Europe; the GDPs per capita (2005 figures) were: $\$ 16,300$ for Hungary; $\$ 21,600$ for Slovenia; and $\$ 30,300$ for the UK. In March 2004, Slovenia became the first transition country to graduate from borrower status to donor partner at the World Bank. The United Kingdom is one of the leading G8 economies of the world, is well developed and mature, and also differs from our two New European economies in terms of Hofstede's (Hofstede, 2001) uncertainty avoidance index $(\mathrm{UAI}=35$ in the $\mathrm{UK}, \mathrm{UAI}=88$ in Slovenia and $\mathrm{UAI}=82$ in Hungary).

Furthermore, according to World Bank statistics (2006), Slovenia is between Hungary and the UK in terms of primary school education (Hungary $=89 \%$, Slovenia $=96.4 \%$ and $U K=100 \%$ ), and life expectancy at birth (Hungary $=72.6$ years, Slovenia $=76.6$ and $U K=78.5$ ).

The same sampling frame was used for the three countries, covering firms employing more than 20 people, stratified by size into small (20-99 employees), medium (100-499 employees) and large (500 or more employees), from industries including consumer products, consumer services, business products, and business services. Since we use constructs developed in one cultural context and apply them in another (etic approach) (Berry, 1969), we tested for construct equivalence by conducting eight in-depth interviews with managing and marketing directors. The constructs were translated into the local language (for Hungary and Slovenia) and translation equivalence was tested through back translation. Further, the questionnaire was pilot tested prior to the main study. This allowed for minor questionnaire refinements and ensured that all scaling and measurement units were usable. The surveys were sent to the chief marketing executive of the firm (3000 in Hungary, 2551 in Slovenia, and 5000 in the UK). Two weeks later, a second copy of the survey was sent to non-respondents. We ended up with 1818 usable surveys (487 from the UK, 759 from Slovenia, and 572 from Hungary). Given the seniority of the managers targeted, the response rates were not surprising -19 percent in Hungary, 30 percent in Slovenia and 10 percent in the UK (Diamantopoulos \& Schlegelmilch, 1996). We did not find any evidence of non-response bias in our comparison of the data from firms that responded in the first wave of our survey with those that responded to the second (Armstrong \& Overton, 1977).

\subsection{Measures}

The survey instrument included psychometric scales to measure organizational innovativeness, customer orientation, customer service performance, product differentiation, financial performance and sustainable competitive advantage. These measures are shown in Table 1 and are described below. 
Given that the majority of the items in the Deshpandé and Farley (1998) customer focus scale were drawn from the Narver and Slater culture-based scale of customer orientation, we chose to use items from the original Narver and Slater scale (1990). Firm customer orientation was measured by asking respondents how much each statement described their company with a 7point scale $(1=$ not at all, $7=$ to an extreme extent $)$ while all other measures utilized a 5-point Likert-type scale ( $1=$ strongly disagree, $5=$ strongly agree). Organizational innovativeness has been described as a key component of success as it is through innovativeness that managers devise solutions to business problems and challenges (Hult, Hurley, \& Knight, 2004). Therefore, we selected a firm-level orientation measure rather than an outcome oriented measure - we operationalize organizational innovativeness as the firm's tendency relative to the competition to initiate new procedures or systems and engage in more innovative processes in order to achieve targets and objectives (West \& Anderson, 2003). Such an ability to reconfigure resources creates the potential for firms to achieve new and innovative forms of competitive advantage (Teece, Pisano, \& Shuen, 1997).

Our measure of firm customer service performance is rooted in the service quality determinants specified by Parasuraman, Zeithaml and Berry (1985) as well as in the customer service expectations described by Grönroos (1997). While customer service performance can include a number of different dimensions, we focused on a resource that must be managed efficiently and effectively by the firm: customer's time (Grönroos, 1997). Time is a limited resource that can be viewed as a cost by the customer (Anderson \& Shugan, 1991). Therefore, as customers require increased levels of convenience, firms need to be more responsive in their handling of deliveries and in providing more immediate resolutions to customer problems, issues, or complaints (Berry, Seiders, \& Grewal, 2002).

According to Michael Porter, a product is differentiated "when it provides something unique that is valuable to buyers beyond simply offering a low price" (Porter, 1980); new product uniqueness is an important attribute of differential advantage (Cooper, 1983). Further, competitive advantage is dependent upon offering products that are different and more innovative (Gatignon \& Xuereb, 1997). We therefore measured product differentiation based on a scale that examines the degree of product innovation and uniqueness relative to the 
firm's main competitors, which are common items for measuring product advantage in the NPD literature (Langerak, Hultink, \& Robben, 2004).

We also employed two different organizational performance measures: relative firm financial performance and sustainable competitive advantage. We used a three item scale to measure a firm's financial performance relative to competing firms. The items on this scale are widely used in the literature and asked respondents to assess the level of overall profits, profit margins, and return on investment relative to the competition. Additionally, a sustainable competitive advantage scale was developed based on a resource-based view of the firm that assesses how advantage is protected through the uniqueness and scarcity of underlying resources (Barney, 1991).

\subsection{Control variables}

We used two control variables in our model: firm size and product technical quality. Company size was defined by the number of employees in a manner consistent with past research relating a firm size to that firm's ability to innovate (Chandy \& Tellis, 2000). Since technology orientation may be considered as an additional antecedent to organizational innovativeness, we used the technical quality of the firm's products and services compared to their main competitors as a proxy measure for this type of orientation ${ }^{2}$.

\section{Analysis and results}

\subsection{Reliability, Validity and Measurement Invariance}

We subjected all scales to a purification process that involved a series of dimensionality, reliability, and validity assessments (Anderson \& Gerbing, 1988; Netemeyer, Durvasula, \& Lictenstein, 1991; Steenkamp \& Baumgartner, 1998). We proceeded by independently testing six models - one for each organizational performance measure (financial performance and competitive advantage) for our three countries. Our measures were first analyzed using exploratory factor analysis (EFA). This was followed by separate confirmatory factor analyses (CFA) where all item loadings were significant at the 0.01 level and the average variance extracted (Table 2) exceeded the recommended level of .50, demonstrating adequate convergent validity (Fornell \& Larcker, 1981). Furthermore, based on the recommended fit statistics for the case of the Maximum Likelihood estimation procedure (Hu \& Bentler, 1999),

\footnotetext{
${ }^{2}$ We thank the editor and an anonymous reviewer for providing us with these comments
} 
all of our CFA analyses presented a very good fit (Standardized RMR $<.05, \mathrm{CFI}>.95$ and RMSEA <.05). After confirming the dimensionality of our dataset, the reliability of each construct was also assessed. The respective Joreskög Rhô coefficients for customer orientation, organizational innovativeness, customer service performance, product differentiation, firm profitability, and competitive advantage were found to indicate acceptable internal reliabilities across the three countries (Table 2). Further, the pairwise factor correlations were examined and were found to be significantly different from 1 , establishing discriminant validity.

Prior to examining the applicability of our framework across different countries, our constructs were tested for cross-national equivalence (Steenkamp \& Baumgartner, 1998), meaning that the resulting scales consisted of items where people from different countries responded in a similar manner. In accordance with Steenkamp and Baumgartner's (1998) recommendation, we analyzed measurement variances across the three countries using multiple group confirmatory factor analysis. This was achieved by constraining factor loadings to be equal across all countries that resulted in a non-significant change in chi-square (Byrne, 1993).

Insert Table 2 about here

\subsection{Model results}

Our model (Figure 1) was tested separately with the data from each country using Structural Equation Modeling. The direct effect of organizational innovativeness on performance was also tested because past studies have hypothesized such a relationship (Hult, Hurley, \& Knight, 2004). The estimation method employed was Maximum Likelihood estimation using robust estimators. Although the computation of robust estimators is more demanding, these indicators are able to correct for non-normality in large samples and have been shown to perform better than asymptotic distribution-free GLS methods (Bentler, 2005; Byrne, 2006). Each one of the six models tested demonstrated very good fit (Table 3) with fit statistics: $\mathrm{CFI}>0.97$; NNFI $>0.95$; RMSEA $<0.05$; $\mathrm{SRMR}<0.06$ (Bentler, 1992; Browne \& Cudeck, 1989; Hu \& Bentler, 1999). In addition, the values of the normalized chi-square measure $\left(\chi^{2} / \mathrm{df}\right)$ did have values between 1.0 and 5.0, which is the range of acceptance (Schumacker \& Lomax, 1996). Tables 4a and 4b present the Maximum Likelihood (ML) standardized path estimates for the hypothesized paths of our model. 


\subsection{Conceptual framework testing}

As our model results indicate (Table 4), customer orientation leads to better served customers more so in our Old European country (UK) than in any of our New European countries $(p<.01)$. This effect is smaller, but still significant in our more developed New European country (Slovenia), whereas this effect is not significant in our lesser developed New European country (Hungary). While customer orientation consistently leads to higher levels of organizational innovativeness across countries, innovativeness leads to better served customers only in New Europe. More specifically, innovativeness has a more significant effect on service performance in Hungary than Slovenia $(p<.05)$, while innovativeness in Slovenia has a more significant effect on service performance than in the UK $(p<.05)$, representing the reverse of the customer orientation effect of noted above. This may be indicative of the less-developed nature of the markets in the two EU accession states, but also suggests that differences also exist between Slovenia and Hungary. Overall, there may be more scope for internal process innovation in New Europe, and when this is achieved, it can improve service to customers more significantly than in Old Europe. In the UK, organizational innovativeness does not appear to add value through service improvements as there might be less room for improvement. Furthermore, the effect of customer service performance on short-term financial performance is strong and positive in all three countries, but service performance does not lead to a sustainable competitive advantage in any of the three markets.

Organizational innovativeness consistently leads to more differentiated products. However, the effect of organizational innovativeness on product differentiation is higher and statistically different in the UK, our Old European country, than in our two New European countries $(p<.05)$. The direct effect of customer orientation on product differentiation also varies by country; the effect is not significant in our two New European economies while in the UK, it is actually negative. A closer examination of the total effect of customer orientation on product differentiation (accounting for the indirect effect of innovativeness) reveals that the overall effect is positive, but significant only in our New European countries (Table 5). This result may seem to provide some support for the argument that excessive customer focus in the UK that is not matched by the appropriate levels of innovativeness may actually deter product differentiation, i.e. listening too much to current customers deters innovation to attract future customers. In addition, the role of innovativeness as the mediator between customer orientation and product differentiation was reconfirmed by separately using the Baron-Kenny 
procedure (Baron \& Kenny, 1986). More specifically, we found organizational innovativeness to fully mediate the relationship between customer orientation and product differentiation in Hungary and Slovenia. However, in the UK, we reconfirmed our previous finding that innovativeness partially mediates the relationship between customer orientation and product differentiation - while the indirect effect of customer orientation through innovativeness is positive and significant, the direct effect is negative and significant as well. Overall, the total effect of customer orientation (both direct and through the mediator) on product differentiation in the UK is positive, but not significant as the direct negative effect cancels the indirect positive effect. A clear conclusion thus emerges: in our Old European country, customer orientation on its own without innovativeness as a mediating factor, is more likely to reduce, rather than enhance, product differentiation. This negative effect may be neutralized by the mediating effect of organizational innovativeness.

While we were originally expecting product differentiation to lead to a higher financial performance, this was not the case in any country. This suggests that while customer service leads to loyal customers in the short term, it is product differentiation that keeps them in the long run. It is postulated that this might be because the service component of the product offering might be easier to imitate, especially in highly competitive industrialized countries. At the same time, innovativeness was found to have a direct effect on financial performance, which may indicate that organizational innovativeness also enables firms to recognize ways to create higher current profitability. However, we find that product differentiation consistently contributes to the creation of a sustainable competitive advantage and that this effect is higher in our emerging New European countries than in the UK, but the differences are not statistically significant. When reviewing our two control variables, product technical quality indeed proved to be an antecedent of innovativeness and product differentiation, while firm size proved to have a negative effect on service performance.

Insert Table 5 about here

The parameter total effects, which account for all indirect effects through mediating variables (Table 5), help us to better understand the interplay between our variables. First, both customer orientation and innovativeness have a significant effect on the two organizational performance measures in all cases except the effect of customer orientation on sustainable competitive advantage in the UK; in the UK, the total effect of customer orientation on sustainable competitive advantage is not statistically significant. Second, it is very important 
to note that the effect of customer orientation on financial performance is not statistically different between our three countries ( $p>.63$ ). Given that customer orientation does contribute to sustainable competitive advantage only in our two New European countries, our findings appear to contradict previous studies that found market orientation to have a lesser effect in Eastern European countries (Ellis, 2006; Kirca, Jayachandran, \& Bearden, 2005). Third, innovativeness has a consistently stronger effect than customer orientation on sustainable competitive advantage in each of our three countries $(p<.05)$. Innovativeness has also a higher effect on financial performance than customer orientation, but this difference is statistically significant in Hungary and Slovenia $(p<.01)$, but not in the UK $(p>.40)$. Fourth, the total effect of innovativeness on financial performance is higher and statistically different in Hungary versus the UK $(p<.05)$; the effect in Slovenia is between the two, and not statistically significant from any of the other two countries ( $p>$.20). It is interesting to note that while model fit is very good across all models, the ability of a model to explain organizational performance depends on the country; for example, the R-square for financial performance in the UK is about $10.5 \%$, for Slovenia $17 \%$ and for Hungary about $28 \%$ (Table $4 \mathrm{~b}$ ).

\section{Discussion}

Although our results are consistent with previous findings that suggest that the combination of customer orientation and organizational innovativeness collectively contribute to the positional advantage of a firm (Hult \& Ketchen, 2001), there are significant lessons that have been learned in terms of the moderating role of national context. Overall, customer orientation practices are particularly effective in enhancing firm-level performance for firms from New European transition economies. While this contradicts previous findings that are based on meta-analyses (Ellis, 2006; Kirca, Jayachandran, \& Bearden, 2005), our study explicitly considered the intervening role of organizational innovativeness, which acts as an enabler for customer orientation practices. Organizational innovativeness is of particular importance as it enhances customer service and financial performance more significantly in New Europe versus Old Europe. Given that we found differences in the underlying market mechanisms, there is much validity in the proposition made by Burgess and Steenkamp (2006) suggesting that research in emerging markets has the potential to advance marketing science and practice. Overall, our core finding is that returns on customer orientation and organizational innovativeness are different in Old and New European countries. 
Across both Old and New European contexts, our findings suggest that customer service performance is consistently linked with financial performance, but not with the achievement of sustainable competitive advantage. However, product differentiation is consistently linked with the achievement of sustainable competitive advantage, but not with financial performance. Innovation leading to differentiation is therefore critical to achieve a sustainable competitive advantage (Atuahene-Gima \& Ko, 2001). In New Europe, firm-level innovativeness serves as a catalyst for both better served customers and more highly differentiated offerings. The direct link between innovativeness and financial performance also suggests that innovative organizations may adopt new processes and methods that are potentially more efficient.

We found that our model's explanatory power with respect to organizational performance varies between Old and New Europe. Specifically in the UK, our mature Old European market, the contribution of organizational innovativeness and customer orientation is more limited as there might be less room for improvement. This indicates the increased difficulty in remaining competitive in mature markets and supports the case for identifying new models that are capable of improving our understanding of organizational performance causes.

\section{Limitations and future research directions}

As with any empirical study, this project has its limitations, which should be noted. Like many studies in strategic marketing and management, this study relies on self-reporting by our key respondents - senior marketing executives. While these respondents are likely to be in the best position to answer questions about strategic orientation and firm performance, other managers may have different, equally valid, perspectives. The in-depth interviews conducted at the outset sought, where possible, independent verification of the opinions of the senior marketing executives and gave confidence that their views were valid representations of their company's approaches and competitive positions. Furthermore, while our response rates are similar to those of other studies conducted in these countries, the response rate in the UK is quite low (10\%). This may also be an indicator of survey fatigue being higher in industrialized versus emerging markets. Two other important issues deal with the possible endogeneity of our model and omitted variable bias. More specifically, a firms' performance may also affect their innovativeness and their customer orientation (i.e. reverse causality can potentially inflate the response parameter). Moreover, the extent to which performance is affected by innovativeness will affect a firm's innovativeness itself. Additionally, a number of 
other orientations are absent, such as a technology and innovation orientation, which could be considered an additional cultural antecedent to organizational innovativeness. We have attempted to partially control for some of these issues with the introduction of two control variables: firm size and product technical quality.

A number of directions for future research are suggested by this work. First, while the combination of high customer orientation and organizational innovativeness has been found to be instrumental in leading product development, for some firms there may be conflicts between these two approaches to business. Achieving a suitable balance between the two, relevant to the market environment in which the firm operates, may be the key. Second, the ease and cost of developing each of these orientations may be significantly different across various countries, and in certain cases, prohibitively high (Atuahene-Gima \& Ko, 2001). Where the combination of these orientations is hard to achieve, or takes time to create, there is likely to be a greater barrier to imitation by competitors. Thus, the role of the combined orientation may become an isolating mechanism (Dierickx \& Cool, 1989; Lippman \& Rumelt, 1982; Reed \& DeFillippi, 1990). 
Fig. 1. The impact of organizational culture and market offerings on firm performance

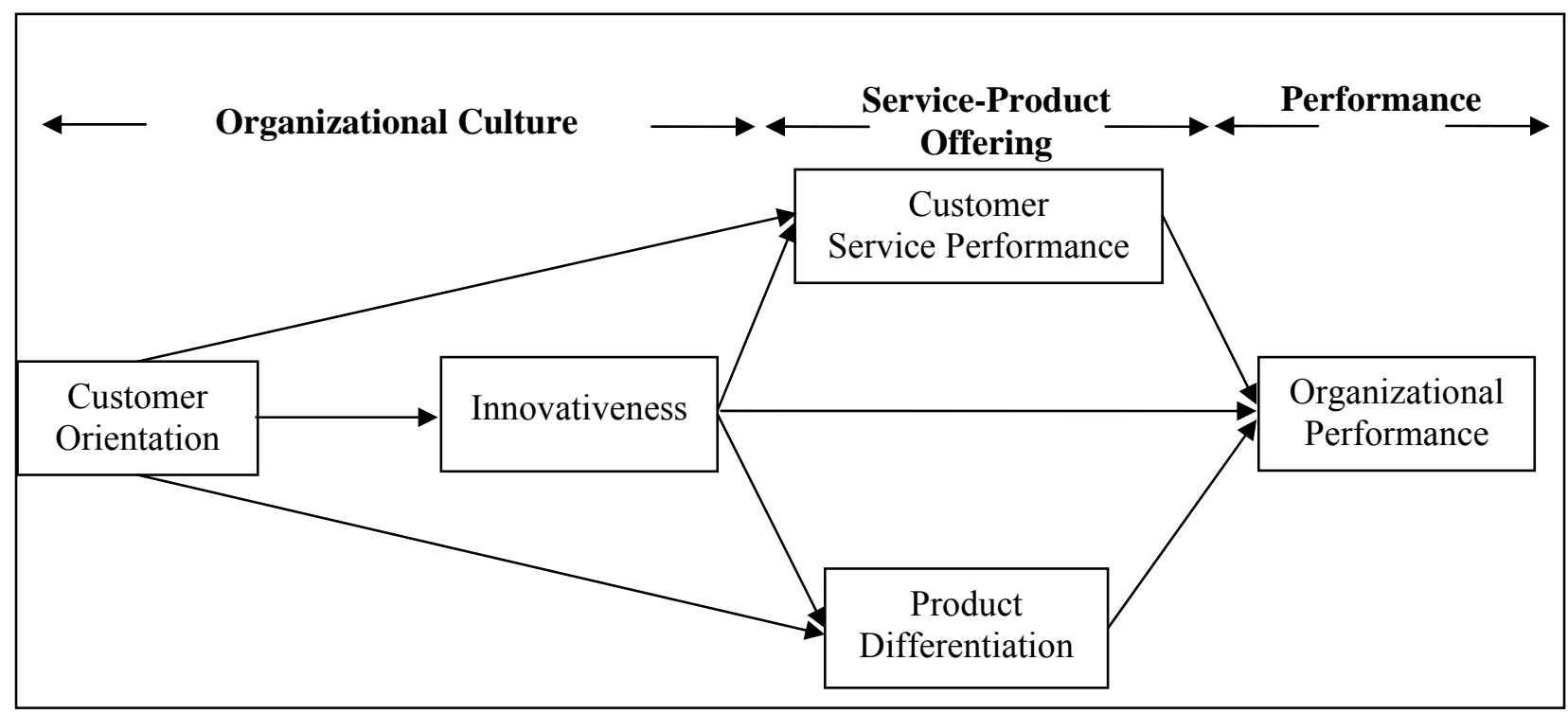

\section{Customer Orientation}

Table 1: Constructs and Scale Items

Our commitment to serving the customer needs is closely monitored Our objectives and strategies are driven by the creation of customer satisfaction Competitive strategies are based on understanding customer needs

Organizational Innovativeness (We are more innovative than our competitors...)

$\ldots$ in deciding what methods to use in achieving our targets and objectives

... in initiating new procedures or systems

$\ldots$ in developing new ways of achieving our targets and objectives

\section{Customer Service Performance}

The speed of delivery to our customers compared to competitors

The degree of responsiveness to customer enquiries and requests compared to competitors

\section{Product Differentiation}

The degree of innovation in our products and services relative to main competitors

The uniqueness of our products and services relative to main competitors

\section{Firm Profitability}

Overall profit levels achieved in the last financial year compared to competitors

Profit margins achieved in the last financial year compared to competitors

\section{Sustainable Competitive Advantage}

Our competitive advantage is difficult for competitors to copy because it uses resources only we have access to It took time to build our competitive advantage \& competitors would find it time-consuming to follow a similar route 
Table 2: Measure Reliabilities for constructs

(Joreskög Rhô/Average Variance Extracted)

\begin{tabular}{lccc}
\hline Measure & Hungary & Slovenia & $\begin{array}{c}\text { United } \\
\text { Kingdom }\end{array}$ \\
\hline $\begin{array}{l}\text { Customer Orientation } \\
\text { Organizational }\end{array}$ & $.75 / .51$ & $.75 / .50$ & $.78 / .55$ \\
$\begin{array}{l}\text { Innovativeness } \\
\text { Customer Service }\end{array}$ & $.80 / .58$ & $.90 / .76$ & $.91 / .78$ \\
$\begin{array}{l}\text { Performance } \\
\text { Product Differentiation }\end{array}$ & $.77 / .62$ & $.76 / .61$ & $.78 / .64$ \\
$\begin{array}{l}\text { Financial Performance } \\
\text { Sustainable Competitive }\end{array}$ & $.91 / .84$ & $.91 / .84$ & $.90 / .82$ \\
Advantage & $.76 / .61$ & $.69 / .53$ & $.67 / .50$ \\
\hline
\end{tabular}

Table 3: Model Fit Indices

\begin{tabular}{|c|c|c|c|c|c|c|}
\hline Country & $\begin{array}{l}\text { Performance } \\
\text { Outcome }\end{array}$ & $\chi^{2}(\mathbf{d f})$ & SRMR & RMSEA & CFI & NNFI \\
\hline \multirow[b]{2}{*}{ Hungary } & $\begin{array}{l}\text { Financial } \\
\text { Performance }\end{array}$ & $\begin{array}{c}112.3 \\
(63)\end{array}$ & .052 & .042 & .972 & .960 \\
\hline & $\begin{array}{l}\text { Sustainable } \\
\text { Competitive } \\
\text { Advantage }\end{array}$ & $\begin{array}{c}104.7 \\
(63)\end{array}$ & .051 & .038 & .973 & .962 \\
\hline \multirow[b]{2}{*}{ Slovenia } & $\begin{array}{l}\text { Financial } \\
\text { Performance }\end{array}$ & $\begin{array}{l}97.3 \\
(63)\end{array}$ & .034 & .029 & .989 & .985 \\
\hline & $\begin{array}{l}\text { Sustainable } \\
\text { Competitive } \\
\text { Advantage }\end{array}$ & $\begin{array}{c}131.9 \\
(63)\end{array}$ & .037 & .042 & .975 & .963 \\
\hline \multirow{2}{*}{$\begin{array}{l}\text { United } \\
\text { Kingdom }\end{array}$} & $\begin{array}{l}\text { Financial } \\
\text { Performance }\end{array}$ & $\begin{array}{c}127.5 \\
(63)\end{array}$ & .035 & .049 & .971 & .958 \\
\hline & $\begin{array}{l}\text { Sustainable } \\
\text { Competitive } \\
\text { Advantage }\end{array}$ & $\begin{array}{c}118.4 \\
(63)\end{array}$ & .037 & .046 & .971 & .958 \\
\hline
\end{tabular}


Table 4a: Standardized Path Estimates (t-values)

\begin{tabular}{|c|c|c|c|c|c|c|}
\hline Country & Performance Outcome & $\begin{array}{c}\text { Customer } \\
\text { Orientation } \rightarrow \\
\text { Customer Service } \\
\text { Performance } \\
\end{array}$ & $\begin{array}{c}\text { Customer } \\
\text { Orientation } \rightarrow \\
\text { Organizational } \\
\text { Innovativeness }\end{array}$ & $\begin{array}{c}\text { Customer } \\
\text { Orientation } \rightarrow \\
\text { Product } \\
\text { Differentiation } \\
\end{array}$ & $\begin{array}{c}\text { Organizational } \\
\text { Innovativeness } \rightarrow \\
\text { Product } \\
\text { Differentiation } \\
\end{array}$ & $\begin{array}{c}\text { Organizational } \\
\text { Innovativeness } \rightarrow \\
\text { Customer Service } \\
\text { Performance } \\
\end{array}$ \\
\hline \multirow[b]{2}{*}{ Hungary } & Financial Performance & $\begin{array}{c}.11 \\
(1.69)\end{array}$ & $\begin{array}{l}.33^{* * *} \\
(4.23)\end{array}$ & $\begin{array}{l}. .02 \\
(-.34)\end{array}$ & $\begin{array}{l}.40 \\
(5.32)\end{array}$ & $\begin{array}{l}.38^{* *} \\
(4.67)\end{array}$ \\
\hline & $\begin{array}{c}\text { Sustainable } \\
\text { Competitive Advantage }\end{array}$ & $\begin{array}{c}.11 \\
(1.74)\end{array}$ & $\begin{array}{l}.33^{* *} \\
(4.23)\end{array}$ & $\begin{array}{c}-.02 \\
(-.16)\end{array}$ & $\begin{array}{l}.40^{* *} \\
(5.23)\end{array}$ & $\begin{array}{l}.38^{* *} \\
(4.55)\end{array}$ \\
\hline \multirow[b]{2}{*}{ Slovenia } & Financial Performance & $\begin{array}{c}.25^{* *} \\
(4.23)\end{array}$ & $\begin{array}{l}.32^{* *} \\
(6.32)\end{array}$ & $\begin{array}{l}-.04 \\
(-.89)\end{array}$ & $\begin{array}{l}.48^{* *} \\
(10.06)\end{array}$ & $\begin{array}{c}.23^{* *} \\
(4.31)\end{array}$ \\
\hline & $\begin{array}{c}\text { Sustainable } \\
\text { Competitive Advantage }\end{array}$ & $\begin{array}{l}.25^{* *} \\
(4.18)\end{array}$ & $\begin{array}{l}.32^{* *} \\
(6.35)\end{array}$ & $\begin{array}{c}-.03 \\
(-.79)\end{array}$ & $\begin{array}{l}.49^{* *} \\
(9.18)\end{array}$ & $\begin{array}{l}.23^{* *} \\
(4.27)\end{array}$ \\
\hline \multirow{2}{*}{$\begin{array}{l}\text { United } \\
\text { Kingdom }\end{array}$} & Financial Performance & $\begin{array}{l}.42^{* *} \\
(5.68)\end{array}$ & $\begin{array}{l}.42^{* *} \\
(6.10)\end{array}$ & $\begin{array}{l}-.16^{* *} \\
(-2.69)\end{array}$ & $\begin{array}{c}.60^{* *} \\
(10.48)\end{array}$ & $\begin{array}{c}.11 \\
(1.48)\end{array}$ \\
\hline & $\begin{array}{c}\text { Sustainable } \\
\text { Competitive Advantage }\end{array}$ & $\begin{array}{l}.42^{* *} \\
(5.69)\end{array}$ & $\begin{array}{c}.42^{* *} \\
(6.10)\end{array}$ & $\begin{array}{l}-.15^{* *} \\
(-2.62)\end{array}$ & $\begin{array}{l}.60^{* *} \\
(9.59)\end{array}$ & $\begin{array}{c}.11 \\
(1.46)\end{array}$ \\
\hline
\end{tabular}

${ }^{*} \mathrm{p}<.05,{ }^{* *} \mathrm{p}<.01$ 
Table 4b: Standardized Path Estimates (t-values)

\begin{tabular}{|c|c|c|c|c|c|c|}
\hline & \multicolumn{3}{|c|}{ Financial Performance } & \multicolumn{3}{|c|}{$\begin{array}{c}\text { Sustainable Competitive } \\
\text { Advantage }\end{array}$} \\
\hline & Hungary & Slovenia & UK & Hungary & Slovenia & UK \\
\hline Customer Service & $.27^{* *}$ & $.21^{* *}$ & $.19^{* *}$ & .06 & -.02 & -.02 \\
\hline Performance & $(4.16)$ & $(4.08)$ & $(2.87)$ & $(.92)$ & $(-.24)$ & $(-.28)$ \\
\hline Product Differentiation & $\begin{array}{c}-.07 \\
(-.84)\end{array}$ & $\begin{array}{c}.10 \\
(1.57)\end{array}$ & $\begin{array}{c}.03 \\
(.43)\end{array}$ & $\begin{array}{l}.51^{* *} \\
(3.85)\end{array}$ & $\begin{array}{c}.39^{* *} \\
(3.18)\end{array}$ & $\begin{array}{c}.30^{* *} \\
(2.81)\end{array}$ \\
\hline $\begin{array}{l}\text { Organizational } \\
\text { Innovativeness }\end{array}$ & $\begin{array}{l}.32^{* *} \\
(4.57)\end{array}$ & $\begin{array}{l}.19^{* *} \\
(3.39)\end{array}$ & $\begin{array}{l}.16^{*} \\
(1.98)\end{array}$ & $\begin{array}{l}.07 \\
(.76)\end{array}$ & $\begin{array}{c}.10 \\
(1.34)\end{array}$ & $\begin{array}{c}.10 \\
(1.01)\end{array}$ \\
\hline R-square & .279 & .170 & .105 & .337 & .239 & .149 \\
\hline
\end{tabular}

Table 5: Total Effects of Customer Orientation and Organizational Innovativeness on Other Measures (t-values)

\begin{tabular}{|c|c|c|c|c|c|c|c|c|}
\hline & \multicolumn{2}{|c|}{ Financial Performance } & \multicolumn{2}{|c|}{$\begin{array}{c}\text { Sustainable Competitive } \\
\text { Advantage }\end{array}$} & \multicolumn{2}{|c|}{$\begin{array}{l}\text { Customer Service } \\
\text { Performance }\end{array}$} & \multicolumn{2}{|c|}{ Product Differentiation } \\
\hline & $\begin{array}{c}\text { Customer } \\
\text { Orientation }\end{array}$ & $\begin{array}{l}\text { Organizational } \\
\text { Innovativeness }\end{array}$ & $\begin{array}{c}\text { Customer } \\
\text { Orientation }\end{array}$ & $\begin{array}{l}\text { Organizational } \\
\text { Innovativeness }\end{array}$ & $\begin{array}{c}\text { Customer } \\
\text { Orientation }\end{array}$ & $\begin{array}{l}\text { Organizational } \\
\text { Innovativeness }\end{array}$ & $\begin{array}{c}\text { Customer } \\
\text { Orientation }\end{array}$ & $\begin{array}{l}\text { Organizational } \\
\text { Innovativeness }\end{array}$ \\
\hline \multirow{2}{*}{ Hungary } & $.16^{* *}$ & $.40^{* *}$ & $.10^{*}$ & $.29^{* *}$ & $.24^{* *}$ & $.38^{* *}$ & $.11^{*}$ & $.40^{* *}$ \\
\hline & $(3.90)$ & $(7.52)$ & $(2.13)$ & $(4.23)$ & $(2.92)$ & $(4.55)$ & $(2.26)$ & $(5.23)$ \\
\hline \multirow{2}{*}{ Slovenia } & $.14^{* *}$ & $.28^{* *}$ & $.08^{* \prime}$ & $.29^{* *}$ & $.32^{* *}$ & $.23^{* *}$ & $.11^{* \prime}$ & $.48^{* *}$ \\
\hline & $(4.92)$ & (6.04) & $(2.34)$ & $(5.50)$ & $(4.80)$ & $(4.27)$ & $(2.06)$ & $(9.18)$ \\
\hline \multirow{2}{*}{ UK } & $.16^{* *}$ & $.21^{* *}$ & .06 & $.28^{* *}$ & $.46^{* *}$ & .11 & .09 & $.60^{* *}$ \\
\hline & $(3.74)$ & $(2.98)$ & $(1.28)$ & (3.14) & $(5.03)$ & $(1.48)$ & $(1.27)$ & $(10.48)$ \\
\hline
\end{tabular}




\section{Acknowledgments}

We greatly benefited from the comments of Erik Mooi and Kyriakos Kyriakopoulos. We also appreciate the many constructive comments of the IJRM editors, Stefan Stremersch and

Hubert Gatignon, three anonymous reviewers and the Associate Editor.

\section{References}

Anderson, E. W., \& Shugan, S. M. (1991). Repositioning for changing preferences: The case of beef versus poultry. Journal of Consumer Research, 18(2), 219-232.

Anderson, J., \& Gerbing, D. (1988). Structural equation modeling in practice: A review and recommended two-step approach. Psychological Bulletin, 103(3), 411-423.

Armstrong, J. S., \& Overton, T. (1977). Estimating nonresponse bias in mail surveys. Journal of Marketing Research, 14(3), 396-402.

Atuahene-Gima, K., \& Ko, A. (2001). An empirical investigation of the effect of market orientation and entrepreneurship orientation alignment on product innovation. Organization Science, 12(1), 54-74.

Barney, J. (1991). Firm resources and sustained competitive advantage. Journal of Management, 17(1), 99-120.

Baron, R. M., \& Kenny, D. A. (1986). The moderator-mediator variable distinction in social psychological research: Conceptual, strategic, and statistical considerations. Journal of Personality and Social Psychology, 51(6), 1173-1182.

Bentler, P. M. (1992). On the fit of models to covariances and methodology to the bulletin. Psychological Bulletin, 112(3), 400-404.

Bentler, P. M. (2005). EQS6 structural equations program manual. Encino, CA: Multivariate Software.

Berry, J. W. (1969). On cross-cultural comparability. International Journal of Psychology, 4(2), 119-128.

Berry, L. L. (1995). Relationship marketing of services growing interest, emerging perspectives. Journal of the Academy of Marketing Science, 23(Fall), 236-245.

Berry, L. L., Seiders, K., \& Grewal, D. (2002). Understanding service convenience. Journal of Marketing, 66(3), 1-17.

Berthon, P., Hulbert, J. M., \& Pitt, L. F. (1999). To serve or create. California Management Review, 42(1), 37-58.

Brady, M. K., \& Cronin, J. J. (2001). Customer orientation: Effects on customer service perceptions and outcome behaviors. Journal of Service Research, 3(3), 241-251.

Browne, M., \& Cudeck, R. (1989). Single sample cross-validation indices for covariance structures. Multivariate Behavioral Research, 24(4), 445-455.

Burgess, S. M., \& Steenkamp, J. (2006). Marketing renaissance: How research in emerging markets advances marketing science and practice. International Journal of Research in Marketing, 23(4), 337-356.

Buzzell, R., \& Gale, B. T. (1987). The PIMS principles. New York: The Free Press.

Byrne, B. M. (1993). The Maslach burnout inventory: Testing for factorial validity and invariance across elementary, intermediate and secondary teachers. Journal of Occupational and Organizational Psychology, 66(3), 197-212.

Byrne, B. M. (2006). Structural equation modeling with EQS: Basic concepts, applications, and programming (2nd ed.). Mahwah, New Jersey: Lawrence Erlbaum Associates, Inc.

Cadogan, J., \& Diamantopoulos, A. (1995). Narver and Slater, Kohli and Jaworski, and the market orientation construct: Integration and internationalisation. Journal of Strategic Marketing, 3, 41-60. 
Cano, C. R., Carrillat, F., \& Jaramillo, F. (2004). A meta-analysis of the relationship between market orientation and business performance: Evidence from five continents. International Journal of Research in Marketing, 21(2), 179-200.

Chandy, R. K., \& Tellis, G. J. (2000). The incumbent's curse? Incumbency, size, and radical product innovation. Journal of Marketing, 64(3), 1-17.

Christensen, C. M., \& Bower, J. L. (1996). Customer power, strategic investment, and the failure of leading firms. Strategic Management Journal, 17(3), 197-218.

Cooper, R. G. (1983). The impact of new product strategies. Industrial Marketing Management, 12, 243-256.

Cox, A. J., Hooley, G. J., Beracs, J., Fonfara, K., \& Snoj, B. (1999). The achievement of privatization objectives in central and eastern Europe. In Temezi \& Zalai (Eds.), Back to a market economy (pp. 401-426). Budapest: Akademiai Kiado.

Deshpandé, R., \& Farley, J. U. (1998). Measuring market orientation: A generalization and synthesis. Journal of Market Focused Management, 2(3), 213-232.

Deshpandé, R., \& Farley, J. U. (2004). Organizational culture, market orientation, innovativeness, and firm performance: An international research odyssey. International Journal of Research in Marketing, 21(1), 3-22.

Deshpandé, R., Farley, J. U., \& Webster, F. E. (1993). Corporate culture, customer orientation, and innovativeness in Japanese firms: A quadrad analysis. Journal of Marketing, 57(January), 23-27.

Diamantopoulos, A., \& Hart, S. (1993). Linking market orientation and company performance: Preliminary evidence on Kohli and Jaworski's framework. Journal of Strategic Marketing, 1(2), 93-122.

Diamantopoulos, A., \& Schlegelmilch, B. B. (1996). Determinants of industrial mail survey response: A survey-on-surveys analysis of researchers' and managers' views. Journal of Marketing Management, 12, 505-531.

Dickson, P., \& Ginter, J. (1987). Market segmentation, product differentiation, and marketing strategy. Journal of Marketing, 51(2), 1-10.

Dierickx, I., \& Cool, K. (1989). Asset stock accumulation and sustainability of competitive advantage. Management Science, 35(December), 1504-1551.

Ellis, P. D. (2006). Market orientation and performance: A meta-analysis and cross-national comparisons. Journal of Management Studies, 43(5), 1089-1107.

Fornell, C., \& Larcker, D. (1981). Evaluating structural equation models with unobservable variables and measurement error. Journal of Marketing Research, 18(1), 39-50.

Gaal, B. (2004). The Hungarian collective agricultural marketing and EU accession. In J. Beracs, J. Lehota, I. Piskoti \& G. Rekettye (Eds.), Marketing theory and practice: A hungarian perspective (pp. 314-340). Budapest: Akademiai Kiado.

Gatignon, H., \& Xuereb, J.-M. (1997). Strategic orientation of the firm and new product performance. Journal of Marketing Research, 34(February), 77-90.

Gray, B., Matear, S., Boshoff, C., \& Matheson, P. (1999). Developing a better measure of market orientation. European Journal of Marketing, 32(9/10), 884-903.

Greenley, G. E. (1995). Forms of market orientation in UK companies. Journal of Management Studies, 32(1), 47-66.

Grewal, R., \& Tansuhaj, P. (2001). Building organizational capabilities for managing economic crisis: The role of market orientation and strategic flexibility. Journal of Marketing, 65(2), 67-80.

Grönroos, C. (1997). Value-driven relational marketing: From products to resources and competencies. Journal of Marketing Management, 13(5), 407-419.

Grönroos, C. (1999). Relationship marketing: Challenges for the organization. Journal of Business Research, 46(3), 327-335. 
Hamel, G., \& Prahalad, C. K. (1991). Corporate imagination and expeditionary marketing. Harvard Business Review, 69(July/August), 81-92.

Han, J. K., Kim, N., \& Srivastava, R. K. (1998). Market orientation and organizational performance: Is innovation the missing link? Journal of Marketing, 62(October), 3045.

Henard, D. H., \& Szymanski, D. M. (2001). Why some new products are more successful than others. Journal of Marketing Research, 38(August), 362-375.

Hennig-Thurau, T. (2002). Understanding relationship marketing outcomes: An integration of relational benefits and relationship quality. Journal of Service Research, 4(3), 230-247.

Hofstede, G. (2001). Culture's consequences: Comparing values behaviors, institutions, and organizations across nations (2nd ed.). Thousand Oaks, CA: Sage Publications.

Holzmüller, H. H., \& Stöllnberger, B. (1994). A conceptual framework for country selection in cross-national export studies. In S. T. Cavusgil (Ed.), Advances in international marketing (Vol. 6, pp. 3-24). Greenwich, CT: JAI Press.

Hooley, G. J., Cox, T., Fahy, J., Shipley, D., Beracs, J., Fonfara, K., et al. (2000). Market orientation in the transition economies of central Europe: Tests of the narver and slater market orientation scales. Journal of Business Research, 50(3), 273-285.

Hu, L., \& Bentler, P. M. (1999). Cutoff criteria for fit indexes in covariance structure analysis: Conventional criteria versus new alternatives. Structural Equation Modeling, 6(1), 155.

Hult, G. T., Hurley, R. F., \& Knight, G. A. (2004). Innovativeness: Its antecedents and impact on business performance. Industrial Marketing Management, 33(5), 429-438.

Hult, G. T., \& Ketchen, D. J. (2001). Does market orientation matter? A test of the relationship between positional advantage and performance. Strategic Management Journal, 22(9), 899-906.

Hurley, R. F., \& Hult, G. T. M. (1998). Innovation, market orientation, and organizational learning: An integration and empirical examination. Journal of Marketing, 62(July), 42-54.

Jaworski, B. J., \& Kohli, A. K. (1993). Market orientation: Antecedents and consequences. Journal of Marketing, 57(July), 53-70.

Jaworski, B. J., Kohli, A. K., \& Sahay, A. (2000). Market-driven versus driving markets. Journal of the Academy of Marketing Science, 28(1), 45-54.

Kamakura, W. A., Mittal, V., de Rosa, F., \& Mazzon, J. A. (2002). Assessing the service profit chain. Marketing Science, 21(3), 294-317.

Kirca, A. H., Jayachandran, S., \& Bearden, W. O. (2005). Market orientation: A meta-analytic review and assessment of its antecedents and impact on performance. Journal of Marketing, 69(April), 24-41.

Kuester, S., Homburg, C., \& Robertson, T. S. (1999). Retaliatory behavior to new product entry. Journal of Marketing, 63(October), 90-106.

Langerak, F. (2003). An appraisal of research on the predictive power of market orientation. European Management Journal, 21(4), 447-464.

Langerak, F., Hultink, E. J., \& Robben, H. (2004). The impact of market orientation, product advantage, and launch proficiency on new product performance and organizational performance. Journal of Product Innovation Management, 21(2), 79-94.

Lemmens, A., Croux, C., \& Dekimpe, M. G. (2007). Consumer confidence in Europe: United in diversity? International Journal of Research in Marketing, 24(2), 113-127.

Leskiewicz Sandvik, I., \& Sandvik, K. (2003). The impact of market orientation on product innovativeness and business performance. International Journal of Research in Marketing, 20(4), 355-376.

Levitt, T. (1960). Marketing myopia. Harvard Business Review, 38(July-August), 45-56. 
Lippman, S. A., \& Rumelt, R. P. (1982). Uncertain inimitability: An analysis of inter-firm differences in efficiency under competition. Bell Journal of Economics, 13, 418-453.

Liu, S. S., Luo, X. M., \& Shi, Y. Z. (2002). Integrating customer orientation, corporate entrepreneurship, and learning orientation in organizations-in-transition: An empirical study. International Journal of Research in Marketing, 19(4), 367-382.

Menguc, B., \& Auh, S. (2006). Creating a firm-level dynamic capability through capitalizing on market orientation and innovativeness. Journal of the Academy of Marketing Science, 34(1), 63-73.

Money, R. B., \& Colton, D. (2000). The response of the 'new consumer' to promotion in the transition economies of the former soviet bloc. Journal of World Business, 35(2), 189205.

Narver, J. C., \& Slater, S. F. (1990). The effect of a market orientation on business profitability. Journal of Marketing, 54(4), 20-35.

Narver, J. C., Slater, S. F., \& MacLachlan, D. L. (2004). Responsive and proactive market orientation and new-product success. Journal of Product Innovation Management, 21(5), 334-347.

Netemeyer, R. G., Durvasula, S., \& Lictenstein, D. R. (1991). A cross-national assessment of the reliability and validity of the Cetscale. Journal of Marketing Research, 28(3), 320327.

Noble, C. H., Sinha, R. K., \& Kumar, A. (2002). Market orientation and alternative strategic orientations: A longitudinal assessment of performance implications. Journal of Marketing, 66(October), 25-39.

Parasuraman, A., Zeithaml, V. A., \& Berry, L. L. (1985). A conceptual model of service quality and its implications for future research. Journal of Marketing, 49(4), 41-50.

Porter, M. (1980). Competitive strategy. New York: The Free Press.

Reed, R., \& DeFillippi, R. J. (1990). Causal ambiguity, barriers to imitation and sustainable competitive advantage. Academy of Management Review, 15(1), 88-102.

Rindfleisch, A., \& Moorman, C. (2003). Interfirm cooperation and customer orientation. Journal of Marketing Research, 40(4), 421-436.

Rust, R. T., \& Zahorik, A. J. (1993). Customer satisfaction, customer retention and market share. Journal of Retailing, 69(2), 105-111.

Schumacker, R. E., \& Lomax, R. G. (1996). A beginner's guide to structural equation modeling. Mahwah, New Jersey: Lawrence Erlbaum Associates.

Schumpeter, J. (1934). The theory of economic development: An inquiry into profits, capital and the business cycle. Boston, MA: Harvard University Press.

Slater, S. F., \& Narver, J. C. (1995). Market orientation and the learning organization. Journal of Marketing, 59(July), 63-74.

Slater, S. F., \& Narver, J. C. (1998). Customer-led and market-oriented: Let's not confuse the two. Strategic Management Journal, 19(10), 1001-1006.

Slater, S. F., \& Narver, J. C. (2000). The positive effect of a market orientation on business profitability: A balanced replication. Journal of Business Research, 48, 69-73.

Slovene Press Agency, S. (2005, December 27th). Gorenje wants to be leader in state-of-theart home appliances. Slovenia Business Week.

Steenkamp, J.-B. E. M., \& Baumgartner, H. (1998). Assessing measurement invariance in cross-national consumer research. Journal of Consumer Research, 25(June), 78-90.

Steensma, H. K., Marino, L., Weaver, K. M., \& Dickson, P. H. (2000). The influence of national culture on the formation of technology alliances by entrepreneurial firms. Academy of Management Journal, 43(5), 951-973.

Stremersch, S., \& Tellis, G. J. (2004). Understanding and managing international growth of new products. International Journal of Research in Marketing, 21(4), 421-438. 
Teece, D. J., Pisano, G., \& Shuen, A. (1997). Dynamic capabilities and strategic management. Strategic Management Journal, 18(7), 509-533.

Vadi, M., \& Suuroja, M. (2006). Training retail sales personnel in transition economies: Applying a model of customer-oriented communication. Journal of Retailing and Consumer Services, 13, 339-349.

West, M., \& Anderson, N. (2003). Innovation in top management teams. Journal of Applied Psychology, 81(6), 680-693.

Zver, M., Zivco, T., \& Bobek, V. (2004). Is there a gap in economic culture between eu countries and the transition economies? Managing Global Transitions, 2(1), 31-40. 